\title{
Exploring "Whistle Blower's" Intentions: Exploration Study On University Students
}

\author{
Dodi Wirawan I. \\ Brawijaya University, Malang \\ Email:dodiwirawan@hotmail.com
}

\begin{abstract}
Recently the epidemic corruption case in Indonesia has become increasingly rampant. Efforts to eradicate corruption which has been committed after the reformation era in 1998 do not equal with the corruption proliferation in the decentralization era. In the last five years many corruption cases have been revealed due to the role of whistle blower. This study aimed to explicate the main intentions of whistle blowers who uncover corruption cases. The perception study were conducted on Brawijaya University students so that understanding the intentions of these whistle blowers can be found in the government sector which in fact is a focus of corruption practices. A factor analysis and statistical descriptive analysis were conducted to answer the main question of this study which revealed that there are three main factors in whistle blowing intention and that demographic variables do not affect the perception of whistle blowing intention.
\end{abstract}

Keywords: Corruption, whistle blower, government, factor analysis

\section{INTRODUCTION}

In the reformation era echoed by activist students, the primary demand to transform state systems into democracy is absolute. The corruption practices in the New Order era caused a very complex endless problem which finallyisabbreviated as $K K N$ (Corruption, Collusion and Nepotism). Practicesof eradicating $K K N$ seem to be running in place and in the era of regional autonomy it is even more rampant. In the midst of this nation's efforts to eradicate corruption practices, recently $K P K$ (Corruption Eradication Commission) has voiced the importance of whistle blower role as one of agents to eradicate corruption (Yanto, 2010).

Whistle blower, according to Bowden (2005), is a disclosure of facts by individuals both from within and outside an organization related to wrongdoing in whichthe information is not publicly available. He added that whistleblowers are heroes in truthtelling in which public should know. In countries with high corruption indexes such as South Africa, de Maria (2005) stated the role of whistleblower is very high and the public has a very high initiative in exposing corruption crimes committed by public officials. Moreover, these whistle blowers are protected by legal certainty guarantee (Ramirez, 2007).

In Indonesia, Matondong (2015) arguedit is a must that in thefrankness era the state existsto educate the importance of individuals who dare to reveal $K K N$ practices and should be protected. Indeed, ordinary people certainly do not know what exactly the role of whistle blower is, and how the impact can result from the disclosure of KKN acts committed by public and private officials.

Due to these problems along with rare research in this field in the Indonesian context, this study wanted to make an initial study regarding the main motive of whistle blowers in an attempt to dismantle corruption cases. In this study, intentions of whistle 
blowers were explored and later would have implications in developing the quality of human resources through understanding the importance of becoming agents of change which is free from corruption and promoteshighlyprofessional performance.

Therefore the purposes of this study are : (1) to find out whether the whistle blowing intentions developed in Africa have the same factorvariation as Indonesian context and (2) to find out whether the demographic factor affects the perception of whistle blowing intentions within the organization

\section{LITERATURE REVIEW}

Whistleblower in literature study is often identical with literature of law science. In English term, it is defined as a "whistle blower" or by some people it is called as "disgrace disclosure".The term whistle blowersin the study of organization, Cooper (2010) mentioned that similar to the role of refereesin a sporting event, they actually serve as a fact disclosure in thegame violation.

The science development in 20th century along with the industrialization and modernization era where the role of business and politics cannot be separated, the term whistleblower is discussed ever more. The occurrence of corruption practices in public and private organizations, in developing countries, and the occurrence of conspiracy tofacilitate business in private companies are due to the role of regulators. Therefore, the role of whistle blower at least givesan apportunity to a scandal exploitation leading to corruption practices (Redfern and Crawford, 2004).

In some developed countries, the role of whistleblowing is governed by relevant statute laws. For example in the United States, under whistleblower act 1989 the role of whistle blower is very protected within the protection of dismissal, proposition of any occupation and disturbance against legal discrimination practices (Jos, et al., 1989). In developed countries, such as South Africa as one of the highest corruption indexesin the world, under the existing Protected Disclosure Act 26/2000 reporters of corruption crime are also subjects of protection regarding the loss of employment and occupation (Lewis and Uys, 2007). Even in Australia, the role of whistle blower is totality protected by Protected Disclosure Act in 1994 in terms of the identity confidentiality guarantee onreporting corruption criminals to public (Callhan, et al., 2003).

Furthermore, in Indonesia, due to the reformation and the desire of all nation's elements to eradicate $K K N$ practices, the government is greatly benefited from the role of whistle blower in exposing corruption cases. Hence, the government needs to provide concrete restrictions on the action of this whistle blower. The whistle blower protection is accomplished by issuing Government Regulation which defines that a whistle blower is "a person who provides information to law enforcement or the commission concerning the occurrence of corruption criminal acts and not a reporter" (PP No. 71/2000). As an effort to protect individuals who reveal facts, an additional regulation was issued namely Government Regulation No. 13/2006 consisting of the protecting witnesses and victims related to the disclosure of corruption practices conducted by whistle blowers.

A healthy organization is the one with a credible and accountable management system. However, it cannot be denied that even good organizations cannot avoid fraudulent practices committed by organizational elements since stakeholders within the organization not only handle internal environments (for example employees, leaders, etc.), 
butalso directly encounter with the external environment (for example government, politics, suppliers, etc.) (Chiu, 2003).

Within an organization the role of whistle blower is to facilitate the disclosure of fraudulent acts by organizational elements. Chiu (2003) and Hwanget al., (2008) emphasized that at the very least the role of individual whistleblower is the person in the organization where he or sheis genuinely concerned about the sustainability of organization so that he or shetakesan initiative to be a whistle blower so that a truth can be upright. Moreover, Berry (2004) highlighted that if a whistle blowing action is facilitated by an organization it will be a predictor of organizational commitment; then, in the long run it will be a healthy culture so that fraudulent practices within an organization can be avoided and better organizational performance can be achieved.

In this study,the adopted model of whistle blowing intention wastaken from Pilay et al. (2012)whose constructs of whistle blowing proponents consist of (1) Moral Aspects; (2) Motives of Revenge; (3) Uncertainty; (4) Organizational Loyalty; (5) Fear of Falsehood; (6) Organizational Culture; (7) Status. By exploring these constructs in Indonesian context, it is expected that positive aspects can be found to contribute to the avoidance of fraudulent practices widely known in Indonesia as $K K N$ practices. Such research is expected to contribute to stakeholders in the organization; thus they pay attention to the behavior of whistle blower candidates who uncover existing fraudulent practices within an organization in order to save organization and management from fraudulent practices. It can also provide a new repertoire of science about the behavior of fraud whistle in the organization.

\section{METHOD}

In-depth field research was used in this study. The method involved several stages by using some media to obtain accurate data and to allocate good time in the periodofthree months. The chosen method focused on descriptive research, with an emphasis on the indepth literature review of the field under study.The main data collection technique in this study was a survey by using questionnaires distributed to all respondents. They were immediately filled or answered in accordance with available alternative answersbased on Likert scale model measurement method. Furthermore, to provide a more comprehensive understanding, interviews were intensely conducted to see how far the respondents understood the question items existing in the questionnaire as well as using secondary data.

Main variables used in this research adopted from the research of from Somay et al. (2012) namelyvariables of Whistle Blower Intentions consisting of (1) Moral Aspects; (2) Motives of Revenge; (3) Uncertainty; (4) Organizational Loyalty; (5) Fear of Falsehood. In general, the research variables were:

1. Whistle blowing driving factor. This factor assessed whether a person morally wanted to be a whistle blower with no pressure and was free from the motive of revenge. There were 6 (six) question items summarized in this factor.

2. Whistle blowing barrier factor. This factor assessed whether a person due to uncertain circumstances would be loyal to an organization and became a whistle blower to defend the truth. In this factor there were 14 (fourteen) questions. 
3. Whistle Blowing Rejection Factor. This factor indicated someone when acting as a whistle blower was based on the fear aspect of an organization to err. These factors were assessed by 4 (four) questions.

Likert scale was used to measure the whistle blowing intentions with occupying 7 scale models from (1) very strongly disagree to (7) very strongly agree, and with middle scale (4) which was neutral. The use of scale 7 was based on the number of sensitive questions which were required to provide with a neutral value variation so that respondents were not burdened withthem.

Statistical analysis tool used in this research was factor analysis method by SPSS version 17.0 software. A different study by using ANOVA test to find out whether varibale demography had an important role in intention of whistle blower was also executed. In addition, descriptive analysis was conducted to provide more scrutiny on the whistle-blowing intention in its role as an initiator to eradicate corruption.

\section{RESULTS}

Through observation and random interviews, the obtained information was that the majority of respondents hadalreadyownedbasic knowledge about the possibility of whistle blower existence within an organization. It was based on their knowledge from reading mass media, watching television or listening to radio about the rampant corruption cases in Indonesia, and involved a lot of whistle blowing actors. The most embedded figure in respondents' viewwasa person named Nazaruddin, who was identical to the whistle blower actor in the context of this research. Giventhis basis, we believed that by distributing questionnaires to respondentswith their knowledge of "whistle blower",this exploratory study could provide an overview of whistle blower instruments in Indonesian context.

By considering the composition of educational respondents, $61 \%$ of recipients was undergraduate study from high school; and $39 \%$ was in master program study frombachelor degree. Based on the composition of respondents' origin, the majority (60\%) came from East Java and the least was from Sumatera (1\%). While from the gendercomposition, 59\% of respondents was female, and the rest (41\%) was male. Furthermore, from the age composition of respondents, the majority was in the range of $18-25$ years old (85\%) and only $1 \%$ was between $41-50$ years old. Regarding the religious composition of respondents, the majority wasMoslem (91\%) and only $9 \%$ was Christian (non-Moslem).

In the factor analysis, the study used SPSS software version 17 . To achieve robust results, we observed whether there were outliers which would influence the results of factor analysis, by adopting techniques developed by Weinberg and Abramowitz (2008) namely $\mathrm{Z}$ scores, in which none of question items in the questionnaire had a value between \pm 3 to \pm 4 . From the data of this study, there was no deviation of outliers.

In the factor analysis, it followed several signs (Hair, 2006): (1) Only eigenvalues> 1 was maintained in the next process; (2)To achieve meaningful factor results, only factor with loading> 0.40 was used for further analysis and in-depth interpretation; (3) To achieve clear factor demensibility, factor analysis was done several times to see the factor pattern free from multiple loading.

The study results showed that from 24 questionitems, Kaiser-Meyer-Olkin (KMO) value 0.804 was obtained and classified as large for a sample of 80 respondents. The 
factor extract was 3 (three) which was consistent with factors developed by Somay et al. (2012). Analysis results also showed that through the method of component principal rotation with varimax method,the obtained value was $55 \%$. With this result, the remaining number of factors was exactly the same factor as Somay et al. (2012). The detailsof factor and loading factor can be seen from appendix 1.

The three conceptually generated factors were summarized in: (1) Whistle blowing driving factor in which factors from Somay et al. were composed of 6 questions.In this studythe new factor was generated with 10 questions in total. They were combinations of Factor 1 and Factor 2 developed by Somay et al. (2) Whistle blowing barrier factor in which factors from Somay et al. were composed of 14 questions.In this research the new factor was resulted from a total of 10 questions which were combinations of Factor 1, Factor 2, and Factor 3 developed by Somay et al. (3) Whistle Blowing Rejection in which factors from Somay et al. were composed of 4 questions.In this study the new factor was produced with questions which were combinations of Factor 1 and Factor 3 developed by Somay et al.

In this study, a different test was also conducted with one-way technique ANOVA of generalized model from SPSS Version 17 program. Some initial steps were taken to achieve optimal results. They can be seen in the thedistribution of respondents' demographic aspects. However, systemically there were some variables which could not be used / were inaccurate in this test sincetheydid not quantitatively meet the minimum standard of analysis operation.

Only the educational and sex variables were those which met the minimum requirements of analysis operation. The analysis was done by applying the regression scores stored from the factor analysis result which had been used, and they automatically met the rules of outliers and inter-correlation since the score result of factor analysis had been standardized.

Table 1. One Way Anova Result

\begin{tabular}{|c|c|c|c|}
\hline No & Demography Variables & $\mathrm{F}$ & Level of Significance \\
\hline 1 & $\begin{aligned} & \text { Hierarchy thrust of whistle blowing } \\
&- \text { Education } \\
&- \text { Gender } \\
&- \text { Education*Gender } \\
&\end{aligned}$ & $\begin{array}{l}5.658 \\
1.166 \\
0.983\end{array}$ & $\begin{array}{l}0.020 / \text { None } \\
0.284 / \text { None } \\
0.325 / \text { None }\end{array}$ \\
\hline 2 & $\begin{aligned} & \text { Principalblockingof whistle blowing } \\
&- \text { Education } \\
&- \text { Gender } \\
&- \text { Education*Gender }\end{aligned}$ & $\begin{array}{l}6.193 \\
1.746 \\
0.024\end{array}$ & $\begin{array}{l}0.015 / \text { None } \\
0.190 / \text { None } \\
0.877 / \text { None }\end{array}$ \\
\hline 3 & $\begin{array}{l}\text { Normative rejectionof whistle } \\
\text { blowing } \\
\quad \text { - Education } \\
\text { - Gender } \\
\text { - Education*Gender }\end{array}$ & $\begin{array}{l}2.099 \\
0.870 \\
0.192\end{array}$ & $\begin{array}{l}0.152 / \text { None } \\
0.354 / \text { None } \\
0.663 / \text { None }\end{array}$ \\
\hline
\end{tabular}




\section{DISCUSSION}

The interpretation of new factors generated from this study referred to the naming factor from Somay et al.with a little modification reinforced by the argumentation of Indonesian cultural context. The naming factors as well as reasons for naming these new factors:

1. Factor 1: Hierarchy thrust of whistle blowing. Reasons why this factor is emphasized by the word "hierarchy" are because in Indonesia context, the power of distance level is very high and the tendency of respondents to see the existence ofhierarchy within the organization. These result in their preference that taking whistle blower action must be based on organizational formality. This means that someone will report abuses if it is based on a hierarchical line (there is a legal party who gives instruction), not due to personal intentions. It can be seen from several questions in the new factor such as (1) fear of being attacked by co-workers and (2) an unequal power distribution.

2. Factor 2: Principal blocking of whistle blowing. Reasonswhy this factor is emphasized by the word "Principal" are because in Indonesia context, cultural values are still held either normatively (obtained in the context of family environment) or substatively (formation in the school environment) by respondents who still uphold the truth value from aspects of society values and norms. These can be seen from several questions in the new factor such as (1) strong moral stance and (2) upholdinghigh values of social justice and work professionalism.

3. Factor 3: Normative Rejection of Whistle Blowing. Reasonswhy this factor is emphasized by the word "normative" are because respondents feel that to be a whistle blower in the context of Indonesia cannot be separated from religious values. Therefore, becoming a whistle blower when there are diversions in the organization, makes respondents think that it is required to see the their religious context. It can be seen from question items such as (1) fear of being a whistle blower due to religious values and (2) upholding a strong system of rules within the organization.

It can be concluded that this study is still consistent with theresearch from Somay et al. However, in Indonesia context, it is necessary to make new form factors from this studyand give a new naming as discussed above.

Furthermore, to answer the second research objective, itis concluded that from oneway ANOVA analysis (Table 1) in which none of the demographic variables (education and sex) or interaction between the two variables had an influence on the three intiating factors of whistle blowing.It meant that respondents, regardless theireducation level and the gender aspect, did not have different perceptions about formingintentionof whistle blowing. These results of study contradictedresults happened in Malaysia, where Ayop and Arifin (2010) concluded that a person'sintegrity in the initiative to be a whistle blower is largely determined by one's position and the work duration. Thus, in Indonesian context, where intentions of being a whistle blower were still relatively new, respondents sawthat $K K N$ problems when associated with the courage to be a whistle blower in uncovering existing deviations were unaffected by neither education and gender levels, nor interactions between these two demography variables.

In term of managerial implications, as Irawanto, et al., (2011) mentioned that the practices of Javanese value still visible in the organizational life, therefore it may affect the effectiveness of management practices such as how the younger generation are favour more transparent acts in the management process as well as performance appraisal. The situatuonal factors also plays an important roles in making the management practices more 
transparent in the public sector context (Winardi, 2013) such as un fair performance appraisal may trigger the whistle blowing intentions to promote healthier organizational justice practices.

\section{CONCLUSIONS AND RECOMMENDATIONS}

With all the indications, whistle-blowing has enormous consequences for both individuals and organizations. From the management point of view, internal whistle-blowing can be praisedwhen identifying disgrace within the company and allow to eliminate it before they financially harm the organization, intense publicity, and/or litigation. On the other hand, external whistle-blowing is often condemned by management since the exposure of errors often brings adverse publicity. In addition, they can bring financial loss if errors are farreaching and the company is responsible for the involved losses. In contrast, whistle blowers whose their disclosures are found to be true and who provide great benefits for superiors still face significant risks from various types of organizational retaliation, such as ostracism by co-workers, long-term economic disturbances, and psychological aspects.

Based on thesewhistle-blower research data of all factor categories, individual perceptions in Indonesian context are more assertive compared to African context (Somay research, et al.) where formed factors from factor analysis revealed that there areemphases on intention perception to be a whistle blower namely (1) to be a whistle blower driver, an individual needs certainty of hierarchical support; (2) to become a whistle blower barrier, an individual still needs life-support principles; and (3) to be a whistle blowing rival, an individual still needs normative values of his/her lives to uncover existing abuses. Further analysis is required whenit is found that demographic variables such as education and gender levels do not affect respondents' perception whether the whistle blowing intention within the organization is triggered as long as the three factors formed above are certain.

This study has limitations particularly in the methodology aspect. Thus, it is expected that future similar research can accommodate these limitations, and a robust research can be produced. The limitations include:

(1) The type of exploration research using only the main variable namelywhistle blower. By adding other organizational research variables (such as job satisfaction, loyalty, etc.),it can enrich treasures of knowledge on how whistle blowers can affect other organizational variables.

(2) Surveysonly to undergraduate and post-graduate students, many of whom or the majority had never been in organization. Thus, their perceptionswere limited to knowledge of information obtained from mass media. By expanding the research into the organization's employee survey, it is expected that future research results will cover the weaknesses of this study.

This study can provide contribution to the development of whistle blowing instrument in the context of organizational and management research in Indonesia. Also, factors generated in this study can be used for similar research and for reference material to educate KKN eradication either in formal education institutions or in the context of both governmental and private organizations. 


\section{REFERENCES}

Anonim1 (2000). PP No. 71 Tahun 2000 tentang Tata Cara Pelaksanaan Peran Serta Masyarakat dan Pemberian Penghargaan Dalam Pencegahan dan Pemberantasan Tindak Pidana Korupsi

Anonim2 (2006). UU Nomor 13 Tahun 2006 tentang Pelindungan Saksi dan Korban

Alam G. M, Hoque, K. E, Ismail, L., Mirsha, P. K. (2010). ”Do Developing Countries Need Education Laws to Manage Its System or Are Ethics and A Market Driven Approach Sufficient?". African Journal of Business Management, 4(15), 3406-3416

Ayop, M., \& Arifin, M. (2010). Persepsi Terhadap Peranan Whitsleblowing dalam Meningkatkan Integriti Anggota Polis Diraja Malaysia: Satu Kajian ke atas Kontinjen Perak (Doctoral dissertation, Universiti Utara Malaysia).

Berry, B. (2004). "Organizational culture: A framework and strategies for facilitating employee whistleblowing”. Employee Responsibilities and Rights Journal, 16(1), 111.

Bowden, P. (2006). "A comparative analysis of whistleblower protections". Australian Journal of Professional and Applied Ethics, 8(2).

Callahan, E. S., Dworkin, T. M., \& Lewis, D. (2003). "Whistleblowing: Australian, UK, and US Approaches to Disclosure in the Public Interest". Va. J. Int'l L., 44, 879.

Chiu R. K. (2003). "Ethical Judgment and Whistleblowing Intention: Examining the moderating role of locus of control". Journal Business Ethics, 43(1-2), 65-74.

Cooper, C. (2010). Extraordinary circumstances: The journey of a corporate whistleblower. John Wiley \& Sons.

De Maria, W. (2005). Whistleblower protection: is Africa ready?. Public Administration \& Development, 25 (3), 217.

Gerbing, D., W. and J. Anderson, C. (1988). "An updated paradigm for scale development incorporating unidimensionality and its assessment." Journal of Marketing Research, 25,186-192.

Hair, J.F., W. Black, C. et al. (2006). "Multivariate data analysis: A global perspectives. NJ, USA, Pearson Education

Hwang D. A., Staley B., Chan Y. T., Lan J.S. (2008). "Confusian Culture and WhistleBlowing by Proffesional Accountants: An Exploratory study". Management Audit, $23(5), 504-526$

Irawanto, D. W., Ramsey, P. L., \& Ryan, J. C. (2011). Challenge of leading in Javanese culture. Asian Ethnicity, 12(2), 125-139.

Jos, P. H., Tompkins, M. E., \& Hays, S. W. (1989). In praise of difficult people: A portrait of the committed. Public Administration Review, 49(6), 552-61.

King, H, Ill (1999).'The Implications of an Organization's Structure on Whistle-blowing". Journal of Business Ethics, 20 (4) 315-326

Lewis, D., \& Uys, T. (2007). Protecting whistleblowers at work: A comparison of the impact of British and South African legislation. Managerial Law, 49(3), 76-92.

Near, Janet, P., Miceli, P. Marcia (1995). "Effective Whistle-blowing."Academey of Management Review, 20. 679-708

Matondong, F. J. (2015). "Perlindungan Saksi Pelapor (Whistle blower) Dalam Tindak Pidana Korupsi Di Indonesia". LEX CRIMEN, 4(3).

Pallant, J. (2007). SPSS survival manual. Sydney, Allen\&Unwin. 
Pillay, Soma., Dorasamy, Nirmala and Vranic, Vedran. (2012)."Exploring Whistle blowing Intentions in South Africa: A Quantitative analysis." African Journal of Business and Management, 6: 2529-2548

Ramirez, M. K. (2007). Blowing the whistle on whistleblower protection: A tale of reform versus power. University of Cincinnati Law Review, 76(1).

Redfern, K., \& Crawford, J. (2004). "An empirical investigation of the influence of modernisation on the moral judgements of managers in the People's Republic of China". Cross Cultural Management: An International Journal, 11(1), 48-61.

Rothschild, Joyce., MIethe, Terance. (1999)."Whsitle-blower disclousures and management retaliation: The battle to control information about organizaiton corruption." Work and Occupations, 26: 107-128

Winardi, R. D. (2013). “The Influence Of Individual And Situational Factors On LowerLevel Civil Servants'whistle-Blowing Intention In Indonesia”. Journal of Indonesian Economy and Business: JIEB., 28(3), 361.

Yanto, O. (2010). Mafia hukum: membongkar konspirasi dan manipulasi hukum di Indonesia. PT Niaga Swadaya. 


\section{Appendix 1}

\section{List of Items and Loading Factorsof Whistle Blower Instrument}

\begin{tabular}{|c|c|c|c|c|}
\hline No & Question Item & $\begin{array}{l}\text { Factor } \\
1\end{array}$ & $\begin{array}{l}\text { Factor } \\
2\end{array}$ & $\begin{array}{l}\text { Factor } \\
3\end{array}$ \\
\hline 2.4 & Will not be a WB due to fear of organization attack & 0.774 & & \\
\hline 2.5 & Will not be a WB due to fear of co-worker attack & 0.743 & & \\
\hline 3.9 & Will not be a WB due to uneven power distribution & 0.725 & & \\
\hline 3.14 & Will not be a WB due to material orientation & 0.724 & & \\
\hline 3.13 & Will not be a WB due towasted time & 0.717 & & \\
\hline 3.8 & Will not be a WB due to betrayal guilt & 0.714 & & \\
\hline 3.12 & Will not be a WB due to self and family protection & 0.712 & & \\
\hline 3.10 & Will not be a WB due to uncertainty & 0.703 & & \\
\hline 2.2 & Will not be a WB due to high morale & 0.701 & & \\
\hline 3.3 & Will not be a WB due to fear of media exposure & 0.563 & & \\
\hline 3.8 & Be a WB due to astrong morale stance & & 0.766 & \\
\hline 2.1 & Be a WB due tosocial justice and professionalism & & 0.758 & \\
\hline 3.2 & principles & & 0.700 & \\
\hline 4.2 & Be a WB due toimmoral acts and law violation & & 0.684 & \\
\hline 2.3 & $\mathrm{Be}$ a WB if subordinates break rules & & 0.618 & \\
\hline 4.4 & Be a WB due toexpectation of respect & & 0.603 & \\
\hline 2.5 & Be a WB due tolaw enforcement & & 0.592 & \\
\hline 4.3 & Be a WB due tocoworker encouragement & & 0.582 & \\
\hline 2.6 & Be a WB due toillegal financial system & & 0.575 & \\
\hline \multirow[t]{2}{*}{4.1} & Be a WB torule enforcement & & 0.477 & \\
\hline & Be a WB if superiors break rules & & & \\
\hline 3.6 & Will not be a WB due to fear ofreligious law & & & 0.798 \\
\hline 3.11 & Will not be a WB due to fear of risk & & & 0.796 \\
\hline 3.1 & Will not be a WB since the organisasi already has a & & & 0.788 \\
\hline 2.2 & $\begin{array}{l}\text { strong control Will not be a WB since the organisasi } \\
\text { already has a strong system }\end{array}$ & & & 0.771 \\
\hline
\end{tabular}

